\title{
BMP-2 and TGF/2 Shared Pathways Regulate Endocardial Cell Transformation
}

\author{
Todd A. Townsend ${ }^{\mathrm{a}} \quad$ Jamille Y. Robinson ${ }^{\mathrm{a}}$ Christopher R. Deig ${ }^{\mathrm{a}} \quad$ Cynthia R. Hill $^{\mathrm{a}}$ \\ Andrew Misfeldt ${ }^{\mathrm{b}}$ Gerard C. Blobe ${ }^{\mathrm{c}}$ Joey V. Barnett ${ }^{\mathrm{a}}$ \\ Departments of a Pharmacology and ${ }^{b}$ Cell and Developmental Biology, Vanderbilt University Medical Center, \\ Nashville, Tenn., and 'Departments of Pharmacology and Cancer Biology and Medicine, Duke University, \\ Durham, N.C., USA
}

\section{Key Words}

Transforming growth factor- $\beta \cdot$ Epithelial mesenchymal transformation • Atrioventricular cushion $\cdot$ Heart valve • Receptors

\begin{abstract}
Valvular heart disease is a major cause of mortality and morbidity. Revealing the cellular processes and molecules that regulate valve formation and remodeling is required to develop effective therapies. A key step in valve formation during heart development is the epithelial-mesenchymal transformation (EMT) of a subpopulation of endocardial cells in the atrioventricular cushion (AVC). The type III transforming growth factor- $\beta$ receptor (TGF $\beta$ R3) regulates AVC endocardial cell EMT in vitro and mesenchymal cell differentiation in vivo. Little is known concerning the signaling mechanisms downstream of TGF $\beta$ R3. Here we use endocardial cell EMT in vitro to determine the role of 2 well-characterized downstream TGF $\beta$ signaling pathways in TGF $\beta$ R3-dependent endocardial cell EMT. Targeting of Smad4, the common mediator Smad, demonstrated that Smad signaling is required for EMT in the AVC and TGF $\beta$ R3-dependent EMT stimulated by TGF $\beta 2$ or BMP-2. Although we show that Smads $1,2,3$, and 5 are required for AVC EMT, overexpression of Smad1 or Smad3
\end{abstract}

is not sufficient to induce EMT. Consistent with the activation of the Par6/Smurf1 pathway downstream of TGF $\beta$ R3, targeting ALK5, Par6, or Smurf1 significantly inhibited EMT in response to either TGF 32 or BMP-2. The requirement for ALK5 activity, Par6, and Smurf1 for TGF $\beta$ R3-dependent endocardial cell EMT is consistent with the documented role of this pathway in the dissolution of tight junctions. Taken together, our data demonstrate that TGF $\beta$ R3-dependent endocardial cell EMT stimulated by either TGF $\beta 2$ or BMP- 2 requires $\mathrm{Smad} 4$ and the activation of the Par6/Smurf1 pathway.

Copyright $\odot 2011$ S. Karger AG, Basel

\section{Abbreviations used in this paper}

ALK activin receptor-like kinase

AVC atrioventricular cushion

BMP bone morphogenic protein

EMT epithelial-mesenchymal transformation

OFT outflow tract

TGF $\beta$ transforming growth factor- $\beta$

TGF $\beta R 1$ type I transforming growth factor- $\beta$ receptor

TGF $\beta$ 2 type II transforming growth factor- $\beta$ receptor

TGF $\beta$ R3 type III transforming growth factor- $\beta$ receptor

\section{KARGER}

() 2011 S. Karger AG, Basel

Fax +4161306 1234

E-Mail karger@karger.ch

www.karger.com
Accessible online at: www.karger.com/cto
Dr. Joey V. Barnett

Department of Pharmacology, Vanderbilt University Medical Center Room 476 RRB, 2220 Pierce Avenue

Nashville, TN 37232-6600 (USA)

Tel. +1 615936 1722, Fax +1 615343 6532, E-Mail joey.barnett@vanderbilt.edu 


\section{Introduction}

Valve formation begins between the common atria and ventricle and in the distal outflow tract (OFT) when the heart is a simple tube comprised of 2 concentric cylinders of epithelia separated by a gel-like matrix termed the cardiac jelly. A critical step in valvulogenesis is the transformation of a subpopulation of endocardial cells from the inner cell layer into mesenchymal cells that invade the cardiac jelly and contribute to the valves and septa of the heart [Sadler, 1985]. Transformation occurs at the atrioventricular boundary to initiate formation of the mitral and tricuspid valves and in the OFT to initiate aortic and pulmonary valve formation. Cell transformation depends on factors derived from the myocardium [Bernanke and Markwald, 1982]. Although the later mechanisms of valve maturation are poorly understood it is clear that cushion mesenchyme is critical to the process of valve formation [Sadler, 1985; Keller and Markwald, 1998].

Atrioventricular cushion (AVC) transformation has been studied extensively in avian systems using an in vitro assay in which the AVC is excised and placed on a collagen gel [Barnett and Desgrosellier, 2003]. In this assay, transformation is divided into 3 steps based on cell morphology. Endocardial cells separate from the epithelial sheet and elongate in a step termed activation. Next, the elongated mesenchymal cells enter the matrix, a step termed invasion. Finally, cells migrate through the gel in the migration step. Epithelial-mesenchymal transformation (EMT) is tightly restricted so that endocardial cells in AVC explants undergo EMT whereas endocardial cells in the ventricle do not [Bernanke and Markwald, 1982]. Transforming cells downregulate the endothelial marker PECAM-1 and upregulate smooth muscle $\alpha$-actin and procollagen type I [Brown et al., 1996; Sugi et al., 2004].

TGF $\beta$ is a key regulator of endocardial cell EMT [reviewed in Barnett and Desgrosellier, 2003]. TGF $\beta$ signals through 3 receptors: the type I (TGF $\beta R 1)$, type II (TGFßR2), and type III (TGFßR3) receptors. In the canonical pathway [Shi and Massague, 2003] ligand binding to TGF $\beta R 2$ recruits TGF $\beta R 1$ or activin receptorlike kinase (ALK) 5. The constitutively active kinase of TGF $\beta R 2$ phosphorylates and activates the kinase domain of ALK5 which subsequently phosphorylates and activates downstream receptor-associated (R-) Smads 2 and 3 [Kretzschmar and Massague, 1998]. TGFßR3 or betaglycan has a highly conserved intracellular domain with no catalytic activity [Lopez-Casillas et al., 1991; Wang et al., 1991; Cheifetz et al., 1992]. TGFßR3 is required for
AVC EMT in vitro [Brown et al., 1999] and mesenchymal cell maturation in vivo (unpublished data). Inactivation of Tgfbr 3 in the mouse results in OFT and cushion defects with death at embryonic day 14.5 due to a failure of coronary vessel development [Compton et al., 2007]. In addition to Smads, TGF $\beta$ activates additional downstream effectors including RhoA [Bhowmick et al., 2001; Edlund et al., 2002; Bhowmick et al., 2003; Masszi et al., 2003; Deaton et al., 2005], Ras [Ward et al., 2002], MAP kinases [Bhowmick et al., 2001; Bakin et al., 2002; Xie et al., 2004; Deaton et al., 2005], and PI3K/AKt [Bakin et al., 2000] although the mechanisms by which TGF $\beta$ regulates these effectors are less well described. A signaling pathway has recently been described where Par6 acts downstream of TGF $\beta$ to control apical-basal polarity [Ozdamar et al., 2005]. Par6 is colocalized to the tight junctions with ALK 5 by occludin. TGF $\beta R 2$ is recruited to the tight junctions by TGF $\beta$ addition and phosphorylates Par6 resulting in the recruitment of Smurf1 [Wang et al., 2003]. Smurf1 ubiquitination of RhoA leads to the degradation of RhoA to promote tight junction dissolution and EMT [Bose and Wrana, 2006]. In addition to playing a critical role in heart valve development, endothelial cell EMT also has key roles in pathological processes in adults such as cardiac fibrosis [Zeisberg et al., 2007] and cancer progression [Potenta et al., 2008]. Here we use an in vitro model of endocardial cell transformation to test the hypothesis that Smad and Par6 signaling pathways regulate TGF $\beta R 3$-dependent EMT in endocardial cells.

\section{Materials and Methods}

Construction of Adenoviral Constructs

Adenoviruses were generated [He et al., 1998] and titered as described [Townsend et al., 2008]. Viral titers ranged from $10^{9}$ to $10^{14} \mathrm{pfu} / \mathrm{ml}$. Injections were adjusted to achieve infection of $20-$ $50 \%$ of endocardial cells.

Viral Injections and Collagen Gel Assays

Stage 10-12 chick embryos were harvested, injected with adenovirus, and incubated, and ventricular or AVC explants were excised as described [Desgrosellier et al., 2005]. After 48 h, explants were fixed, and the phenotype of each GFP-expressing cell was scored as described [Desgrosellier et al., 2005; Townsend et al., 2008] (fig. 1d, e).

\section{Ligand and Inhibitor Addition}

Recombinant human TGF $\beta 2$ and BMP-2 (R\&D Systems, Minneapolis, Minn., USA) addition occurred $12 \mathrm{~h}$ after the placement of explants on collagen pads. SB431542 (Sigma-Aldrich, St. Louis, Mo., USA) was added to conditioning media $12 \mathrm{~h}$ prior to the placement of explants on collagen pads. 

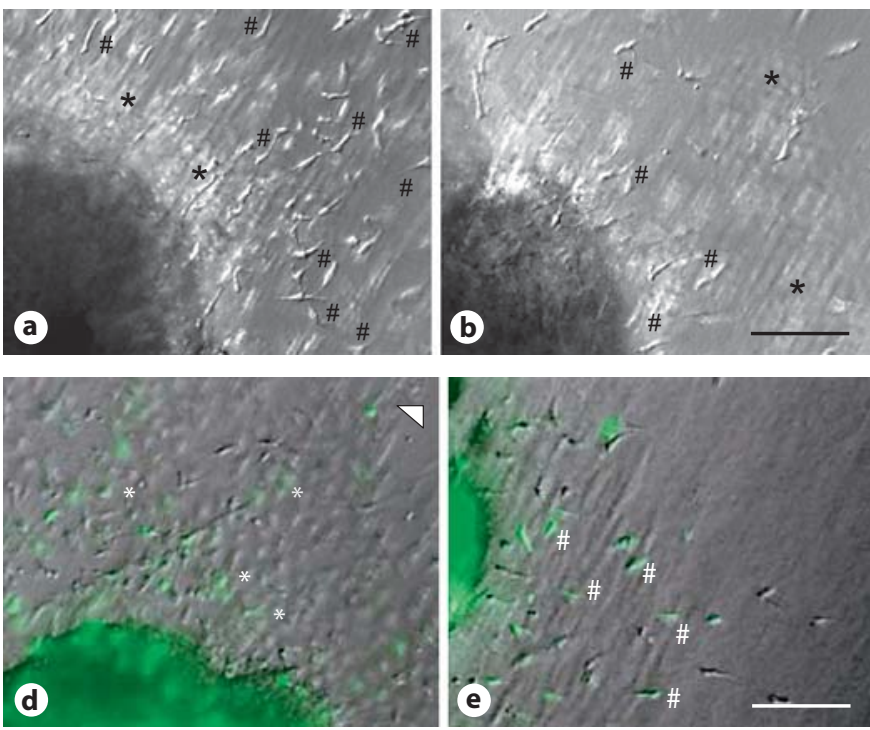

Fig. 1. Smad4 is required for AVC endocardial cell EMT. a, b Representative brightfield photomicrographs of AVC explants incubated with control (a) or Smad4-targeted (b) siRNA. Scale bar = $20 \mu \mathrm{m}$. Cells scored as transformed have elongated, separated from adjacent cells, and entered the collagen pad (\#). Many activated or transformed cells are evident in control explants and are greatly reduced in Smad4 siRNA incubated explants. Rounded, often contiguous cells are scored as epithelial cells $\left(^{*}\right)$. c Quantification of the number of cells in the collagen gel. Data are derived from 3 independent experiments normalized to control-high (HI) siRNA. Endocardial cells from AVC explants incubated either with no addition or with any of 3 independent scrambled control siRNAs with varying GC content [HI 62\%, medium (MID) $38 \%$, and low (LO) 29\%] transformed on collagen gels. However, 2 independent siRNAs targeted against Smad4 inhibited endocardial cell EMT. Control-HI siRNA: normalized to $100 \%$, control-MID siRNA: $97 \pm 4.3 \%$ (mean \pm SEM), control-LO siRNA: $103 \pm$ $6.0 \%$, no addition: $106 \pm 7.7 \%$, Smad4-A siRNA: $39 \pm 2.8 \%$, and Smad4-B siRNA: $36 \pm 3.7 \%$. Two-tailed Student's t test (controlHI vs. specific siRNA) control-MID: $\mathrm{p}=0.549$; control-LO: $\mathrm{p}=$ 0.706; no addition: $\mathrm{p}=0.528 ; \operatorname{Smad} 4-\mathrm{A}: \mathrm{p}=0.002,\left({ }^{*} \mathrm{p}<0.05\right)$, and Smad4-B: $\mathrm{p}=0.003,\left({ }^{*} \mathrm{p}<0.05\right)$. The number of AVC explants examined and the number of cells in each category were as follows: control-HI ( $\mathrm{n}=24$; total number of cells in gel 3,676$), \mathrm{n}=$ number of explants; control-MED ( $\mathrm{n}=24$; total number of cells in gel 3,557); control-LO ( $\mathrm{n}=24$; total number of cells in gel 3,763); no addition ( $\mathrm{n}=24$; total number of cells in gel 3,880); Smad4-A $(\mathrm{n}=24$; total number of cells in gel 1,415$)$, and Smad4-B ( $\mathrm{n}=25$; total number of cells in gel 1,391). d, e Representative merged brightfield and fluorescent photomicrographs of ventricular explants. Scale bar $=20 \mu \mathrm{m}$. d Adenoviral introduction of GFPonly with the plane of focus at the surface of the collagen pad. Rounded, adjacent cells scored as epithelial cells (asterisks) are seen adjacent to the cardiac muscle. Elongated cells in the plane of the surface of the explant are termed activated (arrowhead). e Adenoviral introduction of TGF $\beta$ R 3 and GFP with the plane of focus in the collagen pad. Cells scored as transformed are elongated, separated from adjacent cells, and have entered the collagen pad (\#). f Smad4 is required for TGF $\beta$ R3-dependent, TGF $\beta 2$ -
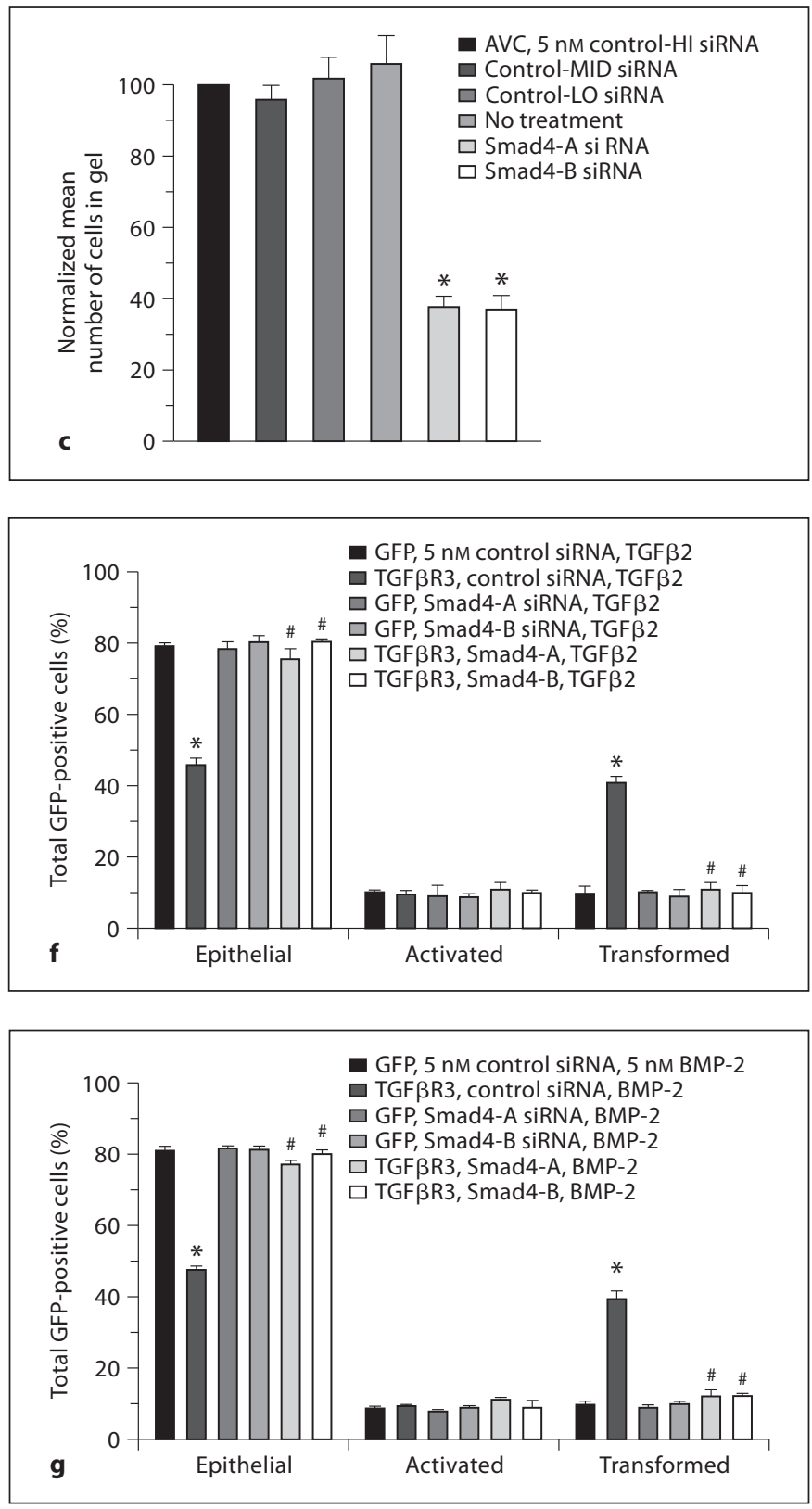

stimulated ventricular endocardial cell EMT. The average percent of total GFP-expressing cells scored as epithelial, activated, or transformed is derived from 3 separate experiments. Two independent Smad4 siRNA constructs blocked TGF $\beta$ R3-dependent EMT whereas control siRNA had no effect. g $\operatorname{Smad} 4$ is required for TGF $\beta R 3$-dependent, BMP-2-stimulated ventricular endocardial cell EMT. The average percent of total GFP-expressing cells scored as epithelial, activated, or transformed is derived from 3 separate experiments. Two independent Smad 4 siRNA constructs blocked TGF $\beta R 3$-dependent EMT whereas control siRNA had no effect. For $\mathbf{f}$ and $\mathbf{g}$, ${ }^{*}$ denotes significance versus ligand-incubated GFP-only-expressing explants whereas \# denotes significance versus ligand-incubated TGF $\beta$ R 3 and GFP-expressing explants. For the actual counts and statistical analysis of $\mathbf{f}$ and $\mathbf{g}$, see online supplementary table 1 . 
siRNA Treatment of AVC and Ventricular Explants

AVC and ventricular explants were harvested and siRNA was introduced as described [Townsend et al., 2008]. Target sequences for Par6 and Smurf1 were as published [Townsend et al., 2008]. Target sequences for ALK5, TGF $\beta R 3$, and the Smads $(1,2,3,5)$ are presented in online supplementary table 2 (for all online suppl. material, see www.karger.com/doi/10.1159/000322035). For control siRNA, 3 scrambled 21-oligonucleotide templates with varying GC content that did not blast to any gene in the chicken genome were designed (online suppl. table 2). The control with the GC content most similar to the target siRNA was used.

RNA Isolation and RT-PCR

Chick embryonic fibroblasts were used to confirm the knockdown of genes targeted with siRNA as described [Townsend et al., 2008] (online suppl. fig. S2). The primers used for RT-PCR of Smurf1 and Par6c were as described [Townsend et al., 2008]. Additional primers used for Smad4; ALK5; TGFßR3; Smads 1, 2, 3, 5 , and GAPDH are presented in the online supplementary material and were used as described [Bushdid et al., 2001]. RT-PCR data was analyzed using the $2^{-\Delta \Delta \mathrm{C}_{\mathrm{T}}}$ method [Livak and Schmittgen, 2001].

\section{Results}

Smads Are Required for Endocardial Cell EMT

TGF $\beta$-stimulated EMT can be Smad-dependent or Smad-independent [reviewed in Lopez-Casillas et al., 1991]. To determine whether Smads are required for endocardial cell EMT, we used siRNA targeted to Smad4. Initially, we delivered siRNA constructs against Smad4 to AVC explants from stage 14 embryos. After incubation with siRNA [Townsend et al., 2008], explants were placed on a collagen gel and fixed and scored after $48 \mathrm{~h}$. As compared to control siRNA, 2 independent siRNA constructs to Smad 4 decreased the number of transformed cells by $60 \%$ (fig. 1a-c). These data demonstrate that endocardial cell EMT at least partially requires Smad4.

To address whether Smad4 is required for TGF $\beta$ R3dependent endocardial cell EMT we took advantage of our prior demonstration that TGF $\beta$ R3 is sufficient and required for endocardial cell EMT in vitro. Overexpression of TGF $3 R 3$ in ventricular endocardial cells, which lack TGF $\beta R 3$ expression, results in EMT after the addition of TGF 32 [Brown et al., 1999] or BMP-2 [Kirkbride et al., 2008] (online suppl. fig. S1). To determine whether TGFßR3-dependent EMT requires Smad4, we overexpressed TGF $\beta R 3$ in ventricular endothelial cells and incubated explants with either control siRNA or 1 of 2 siRNA constructs to Smad4. Stage 10-12 chick embryos were harvested and injected with adenovirus expressing either GFP alone or TGF $\beta$ R3 and GFP. Embryos were cultured for 18-24 h, and ventricular explants from embryos between stages 13 and 15 were excised and placed on collagen gels preincubated with vehicle or siRNA. Twelve hours after explant placement, either vehicle or 200 pM TGF 32 was added, and the incubation continued for $36 \mathrm{~h}$. Explants were fixed and GFP-positive cells were scored as epithelial (round cells in a sheet on the surface of the gel), activated (elongated, individual cells on the surface of the gel), or transformed (elongated, individual cells in the collagen gel) (fig. 1d, e). Infection of cells with a virus that expressed GFP alone defined the basal distribution of the cells. The addition of TGF $\beta 2$ did not alter this distribution [Brown et al., 1999; Townsend et al., 2008] (online suppl. fig. S1). Cells infected with a virus that expressed TGF $\beta R 3$ and GFP incubated with vehicle had a distribution comparable to that of cells infected with virus that expressed GFP alone. The addition of 200 pM TGF $\beta 2$ to cells expressing TGF $\beta$ R3 resulted in a significant increase in the percent of transformed cells and a concomitant decrease in the percent of cells scored as epithelial. Incubation with siRNA to Smad4, but not control siRNA, inhibited the ability of TGF $\beta 2$ to stimulate EMT in TGF $\beta R 3$-expressing cells (fig. 1f). Incubation with control siRNA did not alter the distribution of cells expressing TGF $\beta$ R 3 and incubated with vehicle.

Since BMP-2 also binds TGF $\beta R 3$ and stimulates endocardial cell EMT [Kirkbride et al., 2005] we performed similar experiments where 5nM BMP-2 was added instead of $200 \mathrm{pM}$ TGF $\beta 2$. The addition of $5 \mathrm{nM}$ BMP-2 to explants overexpressing TGF $\beta R 3$ resulted in a significant increase in the percent of transformed cells and a concomitant decrease in the percent of cells scored as epithelial (fig. 1g). Incubation with siRNA against Smad4, but not control siRNA, prevented the ability of BMP-2 to maximally stimulate EMT in TGF $\beta$ R3-expressing cells (fig. 1g). These data demonstrate that $\operatorname{Smad} 4$ is required for BMP-2-stimulated, TGFßR3-dependent EMT in endocardial cells.

\section{Smads Are Required but Are Not Sufficient for Endocardial Cell EMT}

Since Smad4 is required for endocardial cell EMT, we investigated whether specific receptor-regulated Smads are required. Endocardial cell EMT is dependent on ALK5 kinase activity [Townsend et al., 2008]. In addition, both ALK2 and ALK3 have been implicated in endocardial cell EMT [Lai et al., 2000; Desgrosellier et al., 2005; Wang et al., 2005; Song et al., 2007]. Therefore, we targeted Smads downstream of both ALK5 (Smads 2, 3) and ALK2, 3 (Smads 1,5) in AVC explants. We used 2 siRNA constructs 


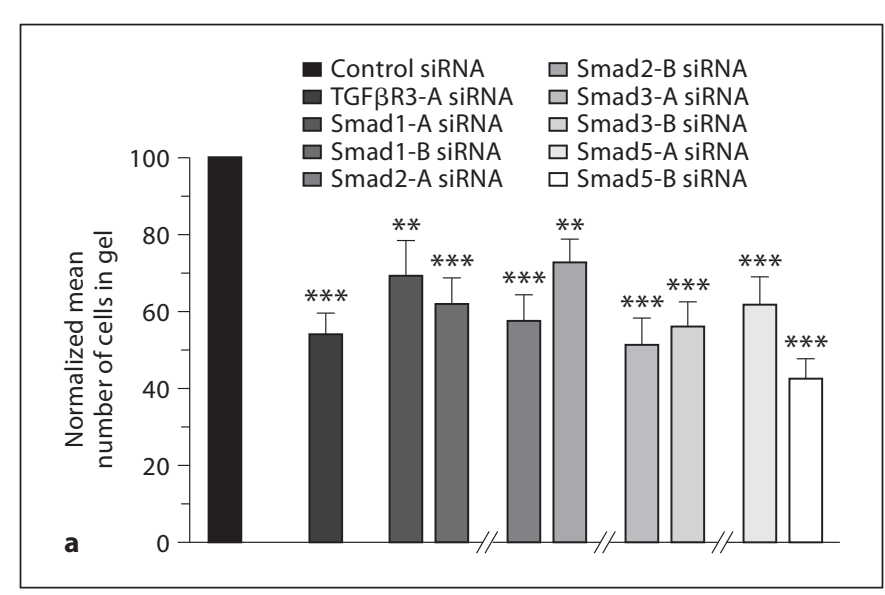

Fig. 2. Smads are required but not sufficient for EMT. a Targeting of Smads 1, 2, 3, and 5. AVC explants were incubated with control, TGFßR3, or Smad specific targeted siRNA. Cells were scored as in fig. 1a-c. Quantification of the number of cells in the collagen gel is depicted. Data are derived from 3 independent experiments normalized to control siRNA. siRNA to TGF $\beta$ R3 is presented as a positive control. Representative controls are depicted and the complete cell counts and controls for each Smad examined are found below. Two-tailed Student's t test (control vs. specific siRNA) TGFßR3: $\mathrm{p}=$ 0.00003; Smad1-A: $\mathrm{p}=0.006$; Smad1-B: $\mathrm{p}=$ 0.0004; Smad2-A: $\mathrm{p}=0.000005$; Smad2-B: $\mathrm{p}=0.002$; Smad3-A: $\mathrm{p}=0.0000006 ;$ Smad3-B: $\mathrm{p}=0.0000008 ;$ Smad5-A: $\mathrm{p}=0.0004$, and Smad5-B: $p=0.0000008,\left({ }^{*} p<0.05\right)$. The number of AVC explants examined and cells in each category were as follows: control ( $\mathrm{n}=31$; total number of cells in gel 4,588), $\mathrm{n}=$ number of explants; TGFßR3 ( $\mathrm{n}=29$; total number of cells in gel 2,297); Smad1-A ( $\mathrm{n}=40$; total number of cells in gel 4,216); Smad1-B ( $\mathrm{n}=47$; total number of cells in gel 4,357); control ( $\mathrm{n}=29$; total number of cells in gel 4,551); TGFßR3 ( $\mathrm{n}=32$; total number of cells in gel 2,979); Smad2-A ( $\mathrm{n}=38$; total number of cells in gel $3,407)$; Smad2-B ( $n=42$; total number of cells in gel 4,728); control $(n=38$; total number of cells in gel 5,499); TGFßR3 $(n=39$; total number of cells in gel 2,796); Smad3-A ( $\mathrm{n}=39$; total number of cells in gel 3,002); Smad3-B ( $n=36$; total number of cells in gel $2,856)$; control ( $\mathrm{n}=25$; total number of cells in gel 3,355$)$; TGF $\beta$ R3

targeted to either Smad 1, 2, 3, or 5, delivered these construct AVC explants from stage 14 embryos, and scored as described above. The targeting of each Smad resulted in a significant decrease in EMT, suggesting that each is required (fig. 2a). We next investigated whether Smad activation is sufficient to induce EMT in endocardial cells. Since overexpression of Smads results in constitutive activity [Edlund et al., 2002] we chose to overexpress Smad1 (downstream of ALK2, ALK3) and Smad3 (downstream of ALK5) independently in ventricular endocardial cells and score for EMT. To confirm that overexpression of Smad1 or Smad3 results in constitutive activity, we as-
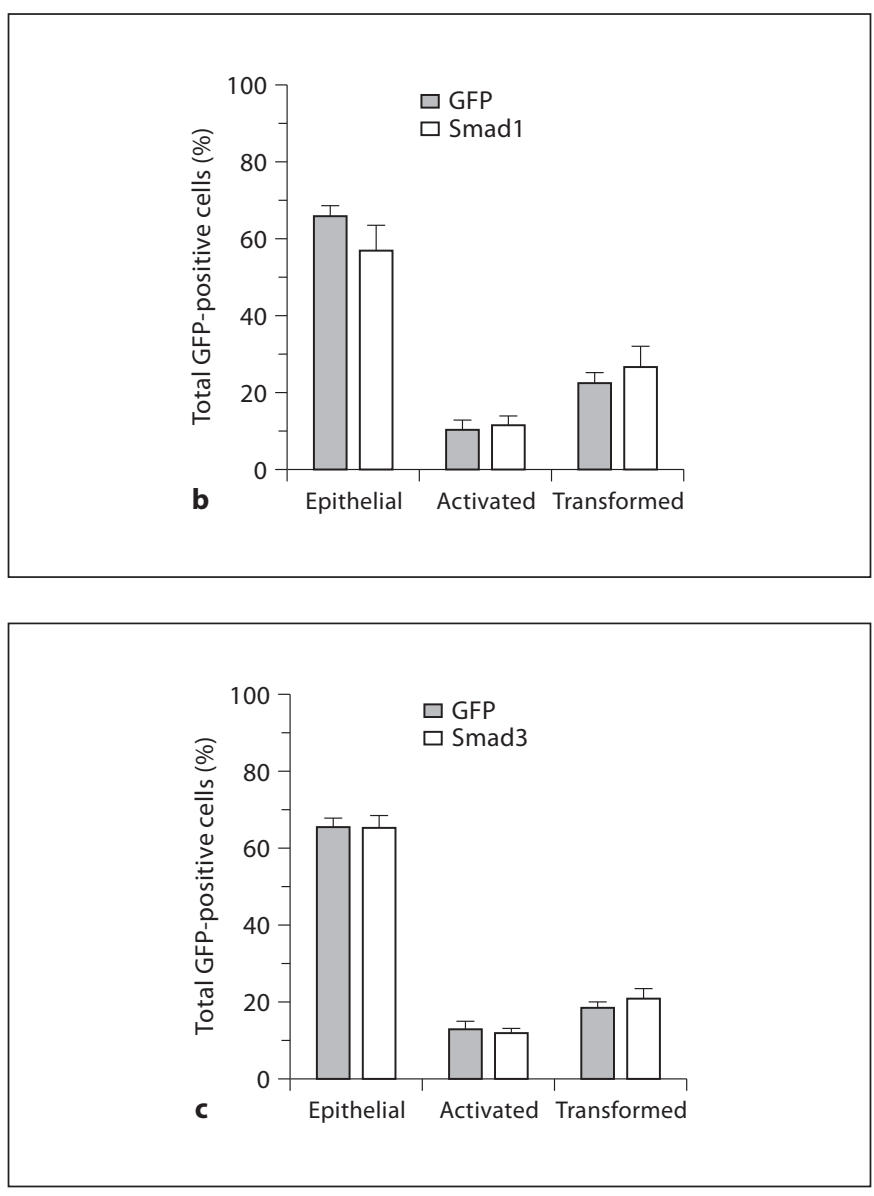

$(\mathrm{n}=23$; total number of cells in gel 1,926); Smad5-A ( $\mathrm{n}=27$; total number of cells in gel 2,198), and Smad5-B $(n=29$; total number of cells in gel 1,686). $\mathbf{b}, \mathbf{c}$ Average percent of total GFP-expressing cells scored as epithelial, activated, or transformed. Means are derived from 3 separate experiments. Neither Smad1 (b) nor Smad3 (c) caused statistically significant changes in transformed, activated, or epithelial cells. For the actual counts and statistical analysis, refer to online supplementary table 1 . sessed the ability of each to activate specific downstream effectors (online suppl. fig. S3B). As expected, expression of Smad1 activated alkaline phosphatase production in C3H10T1/2 cells while Smad3 expression activated the p3TP-lux luciferase reporter. To determine the effects of Smad activation on endocardial cell EMT, embryos were injected, ventricular explants harvested, and cells scored as described above. Neither Smad1 nor Smad3 led to significant differences in the distribution of epithelial, activated, or transformed GFP-positive cells (fig. 2b, c). These data demonstrate that Smad overexpression is not sufficient to induce endocardial cell EMT. 


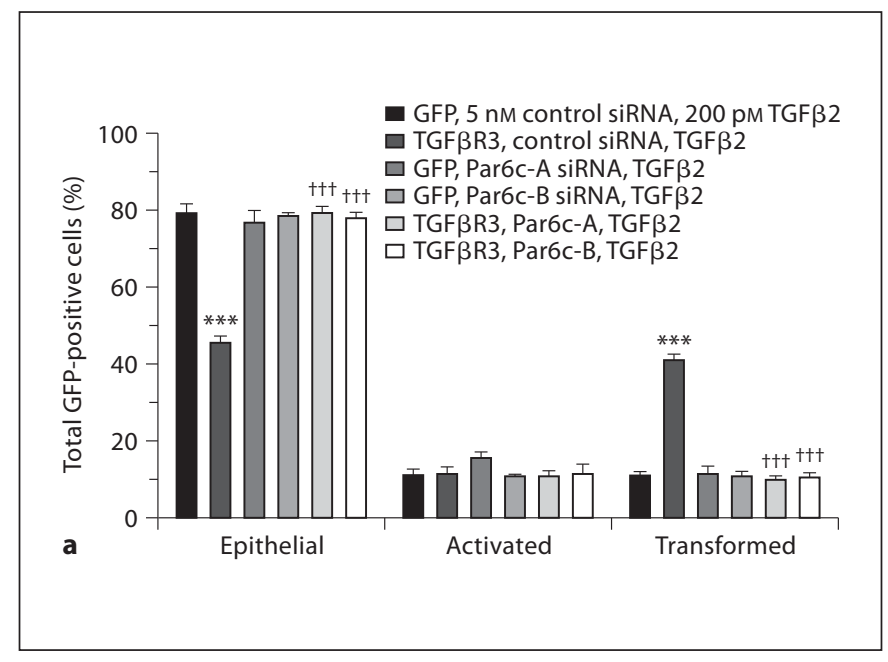

Fig. 3. The Par6c pathway is required for TGF 32 -stimulated, TGFßR3-dependent ventricular endocardial cell EMT. Average percent of total GFP-expressing cells scored as epithelial, activated, or transformed. Means are derived from 3 separate experiments. All explants were given 200 pM TGF $\beta 2$. GFP served as a negative control to determine the basal level of transformation. TGF $\beta R 3$ induced statistically significant increases in transformed cells with a concomitant decrease in epithelial cells. a The addition of 2 independent siRNA constructs targeted against

\section{Par6 Is Required for TGF $\beta 2$-Stimulated,}

\section{TGF $\beta R 3$-Dependent EMT}

Par6 mediates the TGF $\beta$-stimulated dissolution of tight junctions [Ozdamar et al., 2005]. Recently, we showed that the Par6/Smurf1/RhoA pathway is required for EMT in endocardial cells [Townsend et al., 2008]. To test the hypothesis that TGF $\beta$ R3-dependent EMT requires Par6, we overexpressed TGFßR3 in ventricular endothelial cells and incubated explants with either control siRNA or siRNA constructs to Par6 as described [Townsend et al., $2008]$. The addition of TGF $\beta 2$ to cells infected with virus expressing GFP alone did not alter the distribution of cells scored as epithelial, activated, or transformed (fig. 3a). Likewise, the cells infected with virus that expressed TGF $\beta R 3$ and GFP incubated with vehicle had a distribution comparable to that of cells infected with virus that expressed GFP alone (data not shown). However, the addition of 200 pM TGF $\beta 2$ to cells infected with virus that expressed TGF $\beta$ R 3 and GFP resulted in a significant increase in the percent of transformed cells and a concomitant decrease in the percent of cells scored as epithelial. Two siRNA constructs targeted against Par6, but not control siRNA, inhibited the ability of TGF 32 to stimulate EMT in TGFßR3-expressing cells (fig. 3a).

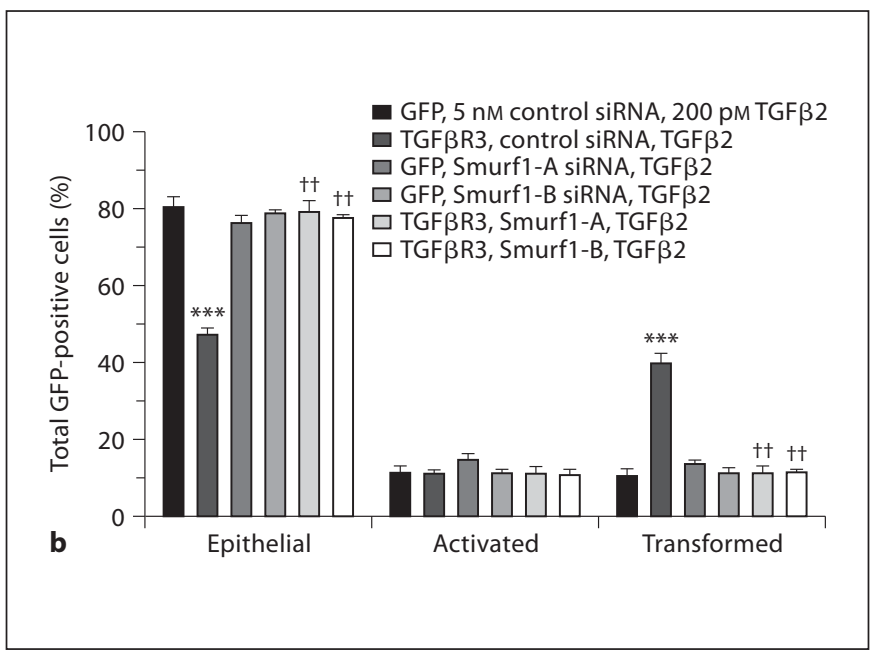

Par6c blocked EMT versus control siRNA. For the actual counts and statistical analysis, refer to online supplementary table 1 . b The addition of 2 independent siRNA constructs targeted against Smurf1 blocked EMT versus control siRNA. For a and b, *** denotes significance versus ligand-incubated GFP-onlyexpressing explants whereas ${ }^{\dagger+}$ and ${ }^{++\dagger}$ denote significance versus ligand-incubated TGF $\beta$ R3- and GFP-expressing explants. For the actual counts and statistical analysis, refer to online supplementary table 1.

Since Par6 is required for TGFßR3-dependent EMT in endocardial cells, we sought to determine whether Smurf1, which is activated downstream of Par6 [Ozdamar et al., 2005], is required for transformation. We delivered siRNA constructs to Smurf1 [Townsend et al., $2008]$ to ventricular endocardial cells infected with adenovirus expressing either GFP alone or TGF $\beta$ R3 and GFP. The addition of $200 \mathrm{pM}$ TGF $\beta 2$ resulted in a significant increase in the percent of transformed cells and a concomitant decrease in the percent of cells scored as epithelial. Incubation with siRNA to Smurf1, but not control siRNA, inhibited the ability of TGF $\beta 2$ to stimulate EMT in TGFßR3-expressing cells (fig. 3b) Taken together, these data demonstrate that the Par6/Smurf1 pathway is required for TGF $\beta R 3$ and TGF $\beta 2$-stimulated EMT.

\section{Par6 is Required for BMP-2-Stimulated, \\ TGF $\beta R 3-D e p e n d e n t$ EMT}

To determine whether BMP-2-stimulated, TGF $\beta$ R3dependent EMT requires the Par6 pathway, we initially wondered whether ALK5 kinase activity was required since ALK5 is known to interact with Par6 directly [Ozdamar et al., 2005]. We overexpressed TGF $\beta R 3$ in ventricular endothelial cells and incubated explants in the 


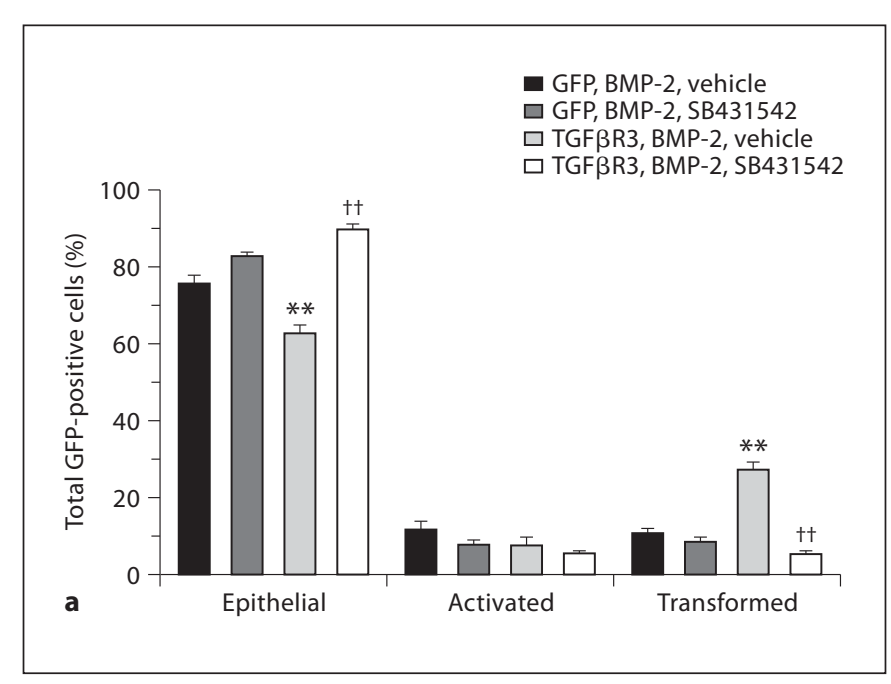

Fig. 4. The Par6c pathway is required for BMP-2-stimulated, TGF $\beta$ R3-dependent ventricular endocardial cell EMT. a-d ALK5 is required for AVC and TGF $\beta R 3$-dependent ventricular endocardial cell EMT. a ALK5 inhibitor blocks BMP-2-stimulated, TGF $\beta R 3$-dependent EMT. Average percent of total GFP-expressing cells scored as epithelial, activated or transformed. Means are derived from 3 separate experiments. All ventricular explants were given $5 \mathrm{nM}$ BMP-2. GFP served as a negative control to determine the basal level of transformation. TGF $\beta R 3$ induced statistically significant increases in transformed cells with a concomitant decrease in epithelial cells. This effect was abolished in the presence of ALK5 kinase inhibitor SB431542. b ALK5-targeted siRNA inhibits AVC endocardial cell EMT. Quantification of AVC endocardial cells migrated into collagen gel. Data are derived from 3 independent experiments normalized to control (LO) siRNA. Endocardial cells from AVC explants given control siRNA transform on collagen gels, whereas 2 independent siRNA constructs targeted to ALK5 inhibit transformation. Control siRNA: normalized to $100 \%$, ALK5-A siRNA: $31 \pm 1.2 \%$, and ALK5-B siRNA: $27 \pm 0.5 \%$. Two-tailed Student's t test (control vs. treatment) ALK5-A: $\mathrm{p}=0.0003\left({ }^{* *} \mathrm{p}<0.001\right)$ and ALK5-B: $\mathrm{p}=0.000042\left({ }^{* * *} \mathrm{p}<0.001\right)$. The number of AVC explants examined and cells in each category were as follows: control $(n=30$; total number of cells in gel 4,694), $\mathrm{n}=$ number of explants; ALK5A ( $n=30$; total number of cells in gel 1,463), and ALK5-B $(n=30$; total number of cells in gel 1,284). c ALK5-targeted siRNA inhibits TGF $\beta 2$-stimulated, TGF $\beta$ R3-dependent ventricular endocar-
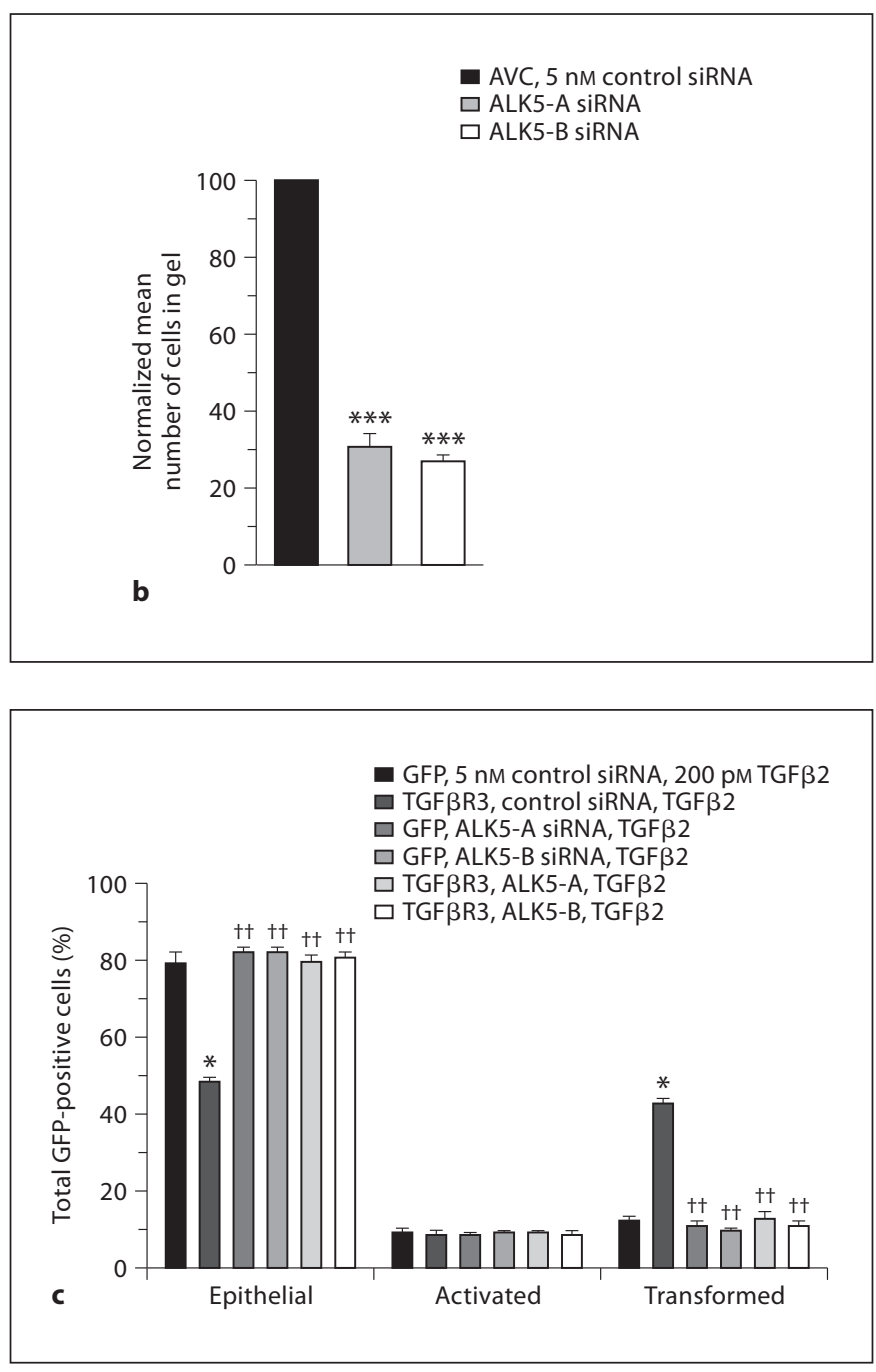

dial cell EMT. Average percent of total GFP-expressing cells scored as epithelial, activated, or transformed. Means are derived from 3 separate experiments. All ventricular explants were given $200 \mathrm{pM}$ TGF $\beta 2$. GFP served as a negative control to determine the basal level of transformation. TGF $\beta$ R3 induced statistically significant increases in transformed cells with a concomitant decrease in epithelial cells. This effect was abolished in the presence of 2 independent siRNAs targeted against ALK5. presence or absence of $2.5 \mu \mathrm{M}$ of the ALK5 kinase inhibitor, SB431542, plus or minus $5 \mathrm{nM}$ BMP-2. The addition of BMP-2 to cells infected with virus expressing GFP alone did not alter the distribution of cells scored as epithelial, activated, or transformed (fig. 4a). Cells infected with virus that expressed TGF $\beta$ R3 and GFP incubated with vehicle had a distribution comparable to that of cells infected with virus that expressed GFP alone (data not shown). In contrast, the addition of $5 \mathrm{nM} \mathrm{BMP-2}$ resulted in a significant increase in the percent of transformed cells and a concomitant decrease in the percent of cells scored as epithelial. These data are consistent with our prior report that BMP-2 stimulates endocardial cell EMT in a TGF $\beta R 3$-dependent manner [Kirkbride et al., 2008]. Incubation with SB431542 inhibited the ability of BMP-2 to stimulate EMT in TGF $\beta$ R3-expressing cells, suggesting 


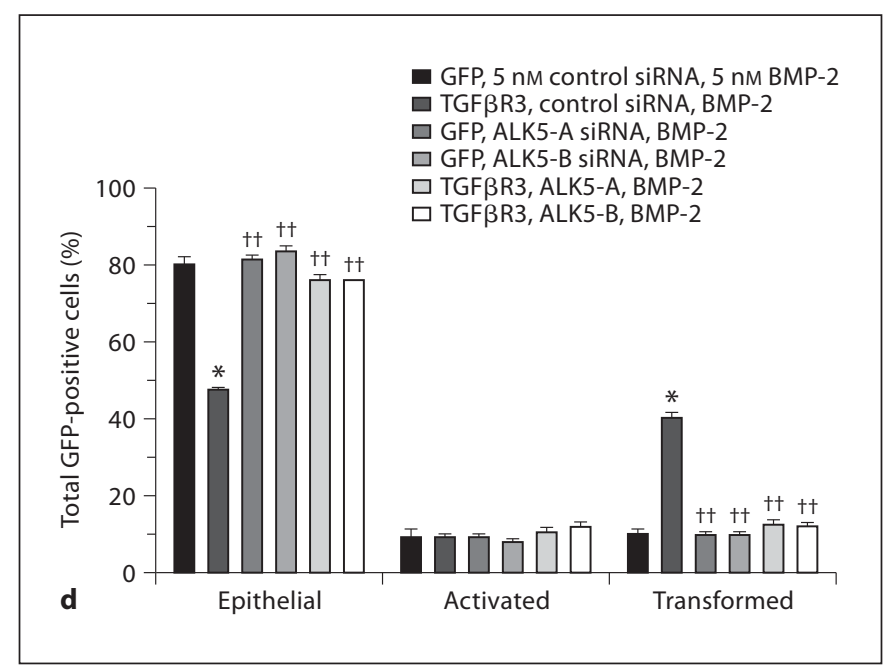

Fig. 4. The Par6c pathway is required for BMP-2-stimulated, TGF $\beta R 3$-dependent ventricular endocardial cell EMT. a-d ALK5 is required for AVC and TGF $\beta R 3$-dependent ventricular endocardial cell EMT. d, e BMP-2-stimulated, TGF $\beta$ R3-dependent ventricular endocardial cell EMT requires intact ALK5/Par6c/ Smurf1 pathway signaling. Average percent of total GFP-expressing cells scored as epithelial, activated or transformed. Means are derived from 3 separate experiments. All ventricular explants were given $5 \mathrm{nM}$ BMP-2. GFP served as a negative control to determine the basal level of transformation. TGF $\beta$ R 3 induced sta-

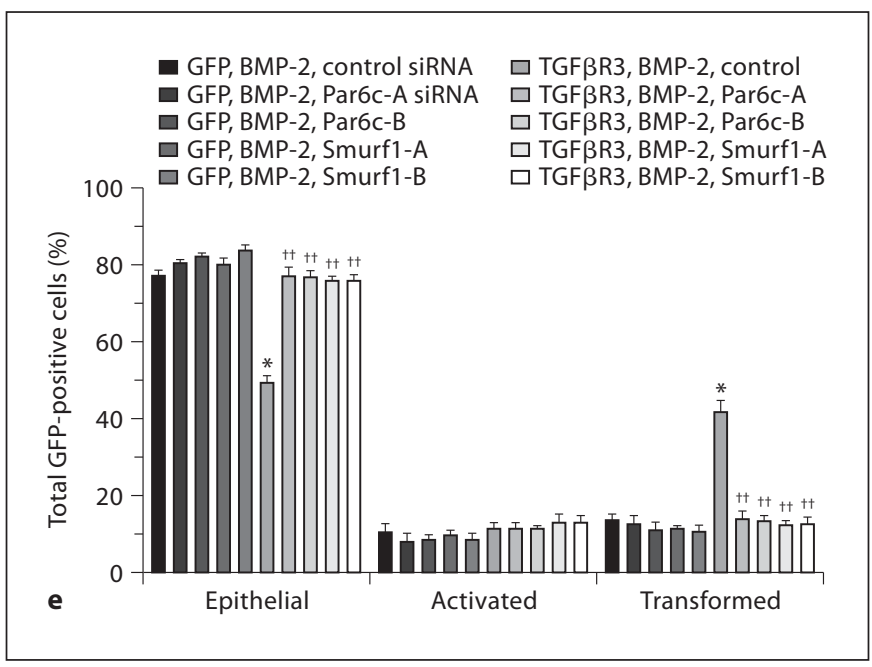

tistically significant increases in transformed cells with a concomitant decrease in epithelial cells. This effect was abolished in the presence of 2 independent siRNAs targeted against ALK5 (d) or 2 independent siRNAs (e) targeted to either Par6c or Smurf1. For a, c-e, * denotes significance versus ligand incubated GFPonly-expressing explants whereas ${ }^{{ }^{\dagger}}$ denotes significance versus ligand-incubated TGF $\beta$ R3 - and GFP-expressing explants. For the actual counts and statistical analysis, refer to online supplementary table 1 . that ALK5 kinase activity is required for BMP-2-stimulated EMT. Incubation with SB431542 did not alter the distribution of cells expressing TGF $\beta$ R 3 and incubated with vehicle. These data are consistent with prior data using ALK5 kinase inhibitors in the AVC and in TGF 32 -stimulated, TGFßR3-dependent EMT [Townsend et al., 2008].

To further establish a role for ALK 5 we used 2 independent siRNAs to ALK5 [Mercado-Pimentel et al., 2007]. Initially, we delivered these constructs to AVC explants from stage 14 embryos. Following incubation with siRNA [Townsend et al., 2008] explants were placed on a collagen gel and fixed and scored after $48 \mathrm{~h}$. As compared to control siRNA, each siRNA construct to ALK5 decreased the number of transformed cells by $60 \%$ (fig. $4 \mathrm{~b}$ ). To address the role of ALK5 downstream of TGF $\beta$ R3, we overexpressed TGF $\beta$ R 3 in ventricular endothelial cells and incubated explants with either control siRNA or 1 of 2 siRNA constructs to ALK5. The addition of TGF 32 (fig. 4c) or BMP2 (fig. 4d) to cells infected with virus expressing GFP alone did not alter the distribution of cells scored as epithelial, activated, or transformed. Cells infected with virus that expressed TGF $\beta$ R 3 and GFP incubated with vehicle had a distribution comparable to that of cells infected with virus that expressed GFP alone (data not shown). However, the addition of 200 pM TGF $\beta 2$ (fig. 4c) or $5 \mathrm{nM} \mathrm{BMP-2} \mathrm{(fig.} \mathrm{4d)} \mathrm{to} \mathrm{cells} \mathrm{infected} \mathrm{with} \mathrm{virus} \mathrm{that}$ overexpressed TGF $\beta$ R 3 and GFP resulted in a significant increase in the percent of transformed cells and a concomitant decrease in the percent of cells scored as epithelial. This ability to undergo EMT is abolished by the addition of 2 independent siRNA constructs targeted against ALK5 (fig. $4 c, d$ ). Therefore, both TGF 32 - and BMP-2-stimulated, TGFßR3-dependent EMT require ALK5.

To further test the hypothesis that BMP-2-stimulated, TGF $\beta R 3$-dependent EMT requires the activation of the Par6 pathway, we overexpressed TGF $\beta$ R3 in ventricular endothelial cells and incubated explants with either control siRNA or siRNA constructs to Par6 as above. Incubation with siRNA against Par6, but not control siRNA, inhibited the ability of BMP-2 to stimulate EMT in TGFßR3-expressing cells (fig. 4e). Similarly, incubation with siRNA against Smurfl, but not control siRNA, inhibited the ability of BMP-2 to stimulate EMT in TGFßR3-expressing cells (fig. 4e). These data demonstrate that Par6 and Smurf1 are required for BMP-2-stimulated, TGFßR3-dependent EMT in endocardial cells. 


\section{Discussion}

TGF $\beta R 3$ facilitates signaling via TGF $\beta R 1 / T G F \beta R 2$ but also appears to play a unique and nonredundant role in TGF $\beta$ signaling. Three lines of evidence support a unique role for TGF $\beta$ R3 in mediating the actions of TGF $\beta$. First, TGF $\beta R 3$ is required for AVC endothelial cell transformation in vitro [Brown et al., 1999]. Second, the deletion of $T g f b 2$, which requires TGF $\beta$ R3 for binding, results in embryos with a unique and nonoverlapping phenotype compared to $T g f \beta 1$ - and $T g f \beta 3$-null animals [Shull et al., 1992]. Finally, the targeted deletion of Tgfbr3 results in embryos with defects distinct from those seen in Tgfbrl and Tgfbr2 nulls [Stenvers et al., 2003; Compton et al., 2007]. Therefore, the determination of the downstream signaling mechanisms of TGF $\beta$ R 3 is likely to provide novel insight into TGF $\beta$ signaling in development and disease.

Here we show that TGF $\beta$ R3-dependent endocardial cell EMT stimulated by either TGF $\beta 2$ or BMP-2 requires both Smad4 and the Par6/Smurf1 signaling pathway. We targeted Smad4, the common mediator Smad, and showed that Smad signaling is required for EMT in the AVC and TGF $\beta R 3$-dependent EMT stimulated by TGF $\beta 2$ or BMP2. We also found that the receptor-regulated Smads $(1,2$, 3 , and 5) are required for EMT, suggesting that both TGF $\beta$ and BMP pathways regulate EMT. However, overexpression of Smad1 or Smad3 does not induce EMT in ventricular endocardial cells. Although overexpression of Smad does not test for the ability of phosphorylated Smads to alter EMT and although Smad phosphorylation in domains outside of the receptor-regulated phosphorylation of the carboxy terminus domain may modulate Smad signaling [Hayashida et al., 2003], our data suggest that Smad signaling, although required for endocardial cell EMT, is not sufficient for EMT. Prior work examined the role of the inhibitory Smad, Smad6, in endocardial cell EMT and valve formation. Smad6-null mice have valvular hyperplasia suggesting either enhanced EMT or mesenchymal cell proliferation in the cushions [Galvin et al., 2000]. Overexpression of Smad6 in the AVC decreased EMT [Desgrosellier et al., 2005]. Since ALK2 activates Smad1 and Smad6 blocks Smad1 signaling [Hata et al., 1998], these data are consistent with the known role of ALK2 in endocardial cell EMT [Desgrosellier et al., 2005; Wang et al., 2005]. Our current data suggest that the ALK2 activation of Smad1 alone is not sufficient to induce EMT and that the activation of additional signaling pathways is required. In the canonical TGF $\beta$ signaling pathway, ligand binding activates ALK5 kinase activity followed by the phosphorylation and subsequent nuclear translocation of Smads [Wrana et al., 1994]. Our prior [Townsend et al., 2008] and current studies reveal a requirement for ALK5 activity downstream of TGF $\beta$ R 3 but suggest that Smad3 activation alone is not sufficient for endocardial cell transformation.

The TGF $\beta$-dependent dissolution of tight junctions in NMuMG cells occurs via the Par6/Smurf1/RhoA pathway and is disassociated from Smad activation [Ozdamar et al., 2005]. We tested whether this pathway regulates TGFßR3-dependent EMT in endocardial cells. Overexpression of TGF $\beta$ R3 in ventricular endocardial cells, followed by TGF $\beta 2$ addition, results in endocardial cell EMT. We previously demonstrated that ALK5 kinase activity is required for TGF $\beta$ R3-dependentEMT [Townsend et al., 2008]. ALK5 activity is required for the activation of Par6 [Ozdamar et al., 2005]. To target the Par6/Smurf1/ RhoA pathway we used siRNA against Par6 and Smurf1 [Townsend et al., 2008]. Consistent with the activation of this pathway downstream of TGF $\beta$ R3, targeting either Par6 or Smurf1 significantly inhibited EMT. The demonstrated requirement for ALK5 activity, Par6, and Smurf1 for TGF $\beta R 3$-dependent endocardial cell EMT is consistent with the documented role of this pathway in the dissolution of tight junctions associated with RhoA degradation [Ozdamar et al., 2005; Townsend et al., 2008]. The regulation of endothelial cell junctional complexes is important during embryonic development, angiogenesis, and leukocyte extravasation [Dejana et al., 2001; Wallez and Huber, 2007]. Further, the ubiquitination of RhoA by Smurf1 may play a role in regulating cell shape change and motility [Bryan et al., 2005; Sahai et al., 2007]. Therefore, TGF $\beta$ R 3 may access this pathway to regulate these processes in response to ligand in several tissues.

Recently, we showed that TGF $\beta$ R3 binds several BMP ligands, including BMP-2, BMP-4, BMP-7, and GDF-5 [Kirkbride et al., 2005]. The BMP subfamily has 20 members with essential roles in development and bone formation [Zhao, 2003; Miyazono et al., 2005]. Specific BMPs elicit distinct effects, yet the mechanism by which a limited number of receptors mediate these effects is unknown. BMP-2 stimulates endocardial cell EMT in a TGF $\beta R 3$-dependent fashion proving the functional significance of BMP-2 binding to TGF $\beta$ R3 [Kirkbride et al., 2005]. Here we show that BMP-2-stimulated, TGF $\beta R 3$ dependent EMT requires ALK5 and Smad4. As with TGF 32 stimulation, BMP-2-stimulated endocardial cell EMT requires Par6 and Smurf1, suggesting that the Par6/Smur1/RhoA pathway is activated downstream of TGF $\beta$ R3 via ALK5 in response to both ligands. 
Mechanistically, how might TGF $\beta R 3$ signal through these diverse pathways to regulate both TGF $\beta 2$ and BMP2-stimulated endocardial cell EMT? Signaling through Smad2/3, Smad1/5, and Smad4 is likely mediated, at least in part, by the traditional role of TGF $\beta R 3$ in binding TGF $\beta$ superfamily ligands [Lopez-Casillas et al., 1993; Kirkbride et al., 2008] and presenting these ligands to their respective TGF $\beta$ superfamily receptors to enhance signaling [Lopez-Casillas et al., 1993; Kirkbride et al., 2008]. However, TGF $\beta R 3$ forms complexes with TGF $\beta$ superfamily receptors and with the scaffolding molecules GIPC [Blobe et al., 2001a] and $\beta$-arrestin2 [Chen et al., 2003], and it has been demonstrated to regulate TGF $\beta$ superfamily receptors trafficking through these interactions to regulate TGF $\beta$ superfamily signaling through both Smad and non-Smad signaling pathways [Chen et al., 2003; You et al., 2007; Finger et al., 2008a; Lee et al., 2009]. In addition, TGF $\beta R 3$, through its interaction with $\beta$-arrestin2, has been demonstrated to mediate signaling to non-Smad pathways, including the NF-kB pathway [You et al., 2009], and to Cdc42 [Mythreye and Blobe, $2009 b]$, independently of other TGF $\beta$ superfamily receptors. Finally, as with other proteoglycan coreceptors [Mythreye and Blobe, 2009a], TGFßR3 might function as a structural/adaptor protein to regulate cell adhesion and migration during EMT. The relative contribution of these diverse roles of TGF $\beta$ R 3 to regulating endocardial cell EMT is currently being explored.

In addition to a prominent role during embryonic development, EMT also has a defined role in mediating several key steps in the metastatic cascade during cancer progression, including invasion through the basement membrane, intravasation, and extravasation [Thiery, 2002]. Accordingly, just as TGF $\beta R 3$ has been demonstrated to have a role in developmental EMTs in the heart [Brown et al., 1999] and palate [Nakajima et al., 2007], TGF $\beta$ R3 has been defined as having a role in EMTs during pancreatic cancer progression [Gordon et al., 2008, 2009] as well as being implicated in breast [Reeves et al., 2001] and skin [Levy and Hill, 2005] EMT models. Indeed, the physiological role of TGFßR3 in inhibiting migration and invasion associated with EMT may be a major mechanism by which TGF $\beta$ R 3 functions as a suppressor of cancer progression or as a metastasis suppressor in a broad spectrum of human cancers [Dong et al., 2007; Hempel et al., 2007; Turley et al., 2007; Finger et al., 2008b; Gordon et al., 2008]. These studies suggest that TGF $\beta$ R3 is another common regulator shared during both developmental and cancer-associated EMT. The mechanism by which TGF $\beta$ R3 expression is regulated during EMT and by which TGF $\beta$ R 3 functions to regulate EMT during both development and cancer progression is currently under investigation.

Our demonstration that both BMP-2 and TGF $\beta 2$ use TGF $\beta R 3$ to access the pathway required to regulate endocardial cell EMT (online suppl. fig. S4) has several implications. First, these data force us to consider the role of BMP-2 signaling in the interpretation of the phenotype of the Tgfbr3-null mouse. Ablation of BMP-2 from the myocardium during development results in failure of the TGFßR3-expressing endothelial cells in the adjacent valve-forming region of the heart to undergo EMT [Ma et al., 2005; Rivera-Feliciano and Tabin, 2006] while the deletion of TGF $\beta 2$ allows EMT but results in inappropriate remodeling of the cushion associated with valvular hyperplasia [Sanford et al., 1997; Bartram et al., 2001]. These data suggest that a second TGF $\beta$ R3-independent, BMP-2-stimulated pathway is present in endocardial cells to support EMT. However, after transformation, the resulting mesenchymal cells are dependent upon TGF $\beta$ R3 signaling to support appropriate remodeling of the cushion. Second, given that endothelial cell EMT is recognized as a mechanism for cardiac fibrosis and cancer progression, TGF $\beta$ R 3 may be a potential therapeutic target for these processes. Lastly, TGF $\beta R 3$ is widely expressed [Blobe et al., 2001b] and is a coreceptor for TGF $\beta$ s, BMPs, and inhibin. Therefore, given the wide tissue distribution of TGF $\beta$ R 3 and its ability to bind and signal via several ligands in the TGF $\beta$ superfamily, TGF $\beta$ R3 is poised to integrate TGF $\beta$ superfamily signaling at the level of the membrane.

\section{Acknowledgements}

We would like to thank Dr. Andries Ziljstra and Tyson Foods, Inc., for the chicken eggs. The authors thank Dr. Christopher Brown for his critical review of the manuscript. This research was supported in part the by the National Institutes of Health, the Heart, Lung and Blood Institute (HL092551; J.V.B.), and the Institute of General Medical Sciences [GM007628 (T.A.T.) and GM062459 (J.Y.R.)]. C.R.D. was supported by the ASPET Summer Undergraduate Research Fellow Program. 


\section{References}

Bakin, A.V., C. Rinehart, A.K. Tomlinson, C.L. Arteaga (2002) p38 mitogen-activated protein kinase is required for TGFbeta-mediated fibroblastic transdifferentiation and cell migration. J Cell Sci 115: 3193-3206.

Bakin, A.V., A.K. Tomlinson, N.A. Bhowmick, H.L. Moses, C.L. Arteaga (2000) Phosphatidylinositol 3-kinase function is required for transforming growth factor beta-mediated epithelial to mesenchymal transition and cell migration. J Biol Chem 275: $36803-$ 36810.

Barnett, J.V., J.S. Desgrosellier (2003) Early events in valvulogenesis: a signaling perspective. Birth Defects Res C Embryo Today 69: 58-72.

Bartram, U., D.G. Molin, L.J. Wisse, A. Mohamad, L.P. Sanford, T. Doetschman, C.P. Speer, R.E. Poelmann, A.C. Gittenberger-de Groot (2001) Double-outlet right ventricle and overriding tricuspid valve reflect disturbances of looping, myocardialization, endocardial cushion differentiation, and apoptosis in TGF-beta(2)-knockout mice. Circulation 103: 2745-2752.

Bernanke, D.H., R.R. Markwald (1982) Migratory behavior of cardiac cushion tissue cells in a collagen-lattice culture system. Dev Biol 91: 235-245.

Bhowmick, N.A., M. Ghiassi, M. Aakre, K. Brown, V. Singh, H.L. Moses (2003) TGF-beta-induced RhoA and p160ROCK activation is involved in the inhibition of Cdc25A with resultant cell-cycle arrest. Proc Natl Acad Sci USA 100: 15548-15553.

Bhowmick, N.A., M. Ghiassi, A. Bakin, M. Aakre, C.A. Lundquist, M.E. Engel, C.L. Arteaga, H.L. Moses (2001) Transforming Growth Factor-beta1 Mediates Epithelial to Mesenchymal Transdifferentiation through a RhoA-dependent Mechanism. Mol Biol Cell 12: 27-36.

Blobe, G.C., X. Liu, S.J. Fang, T. How, H.F. Lodish (2001a) A novel mechanism for regulating transforming growth factor beta (TGF-beta) signaling: functional modulation of type III TGF-beta receptor expression through interaction with the PDZ domain protein, GIPC. J Biol Chem 276: 39608-39617.

Blobe, G.C., W.P. Schiemann, M.C. Pepin, M. Beauchemin, A. Moustakas, H.F. Lodish, M.D. O'Connor-McCourt (2001b) Functional roles for the cytoplasmic domain of the type III transforming growth factor beta receptor in regulating transforming growth factor beta signaling. J Biol Chem 276: 24627-24637.

Bose, R., J.L. Wrana (2006) Regulation of Par6 by extracellular signals. Curr Opin Cell Biol 18: 206-212.

Brown, C.B., A.S. Boyer, R.B. Runyan, J.V. Barnett (1996) Antibodies to the type II TGFbeta receptor block cell activation and migration during atrioventricular cushion transformation in the heart. Dev Biol 174: 248-257.
Brown, C.B., A.S. Boyer, R.B. Runyan, J.V. Barnett (1999) Requirement of type III TGF-beta receptor for endocardial cell transformation in the heart. Science 283: 2080-2082.

Bryan, B., Y. Cai, K. Wrighton, G. Wu, X.H. Feng, M. Liu (2005) Ubiquitination of RhoA by Smurf1 promotes neurite outgrowth. FEBS Lett 579: 1015-1019.

Bushdid, P.B., C.L. Chen, D.M. Brantley, F. Yull, R. Raghow, L.D. Kerr, J.V. Barnett (2001) NFkappaB mediates FGF signal regulation of msx-1 expression. Dev Biol 237: 107-115.

Cheifetz, S., T. Bellon, C. Cales, S. Vera, C. Bernabeu, J. Massague, M. Letarte (1992) Endoglin is a component of the transforming growth factor-beta receptor system in human endothelial cells. J Biol Chem 267: 19027-19030.

Chen, W., K.C. Kirkbride, T. How, C.D. Nelson, J. Mo, J.P. Frederick, X.F. Wang, R.J. Lefkowitz, G.C. Blobe (2003) Beta-arrestin 2 mediates endocytosis of type III TGF-beta receptor and down-regulation of its signaling. Science 301: 1394-1397.

Compton, L.A., D.A. Potash, C.B. Brown, J.V. Barnett (2007) Coronary vessel development is dependent on the type III transforming growth factor beta receptor. Circ Res 101: 784-791.

Deaton, R.A., C. Su, T.G. Valencia, S.R. Grant (2005) Transforming growth factor-beta1induced expression of smooth muscle marker genes involves activation of PKN and p38 MAPK. J Biol Chem 280: 31172-31181.

Dejana, E., R. Spagnuolo, G. Bazzoni (2001) Interendothelial junctions and their role in the control of angiogenesis, vascular permeability and leukocyte transmigration. Thromb Haemost 86: 308-315.

Desgrosellier, J.S., N.A. Mundell, M.A. McDonnell, H.L. Moses, J.V. Barnett (2005) Activin receptor-like kinase 2 and Smad6 regulate epithelial-mesenchymal transformation during cardiac valve formation. Dev Biol 280: 201-210.

Dong, M., T. How, K.C. Kirkbride, K.J. Gordon, J.D. Lee, N. Hempel, P. Kelly, B.J. Moeller, J.R. Marks, G.C. Blobe (2007) The type III TGF-beta receptor suppresses breast cancer progression. J Clin Invest 117: 206-217.

Edlund, S., M. Landstrom, C.-H. Heldin, P. Aspenstrom (2002) Transforming growth factor-beta-induced mobilization of actin cytoskeleton requires signaling by small GTPases Cdc42 and RhoA. Mol Biol Cell 13: 902-914.

Finger, E.C., N.Y. Lee, H.J. You, G.C. Blobe (2008a) Endocytosis of the type III TGF-beta receptor through the clathrin-independent/ lipid raft pathway regulates TGF-beta signaling and receptor downregulation. J Biol Chem 283: 34808-34818.
Finger, E.C., R.S. Turley, M. Dong, T. How, T.A. Fields, G.C. Blobe (2008b) TbetaRIII suppresses non-small cell lung cancer invasiveness and tumorigenicity. Carcinogenesis 29: 528-535.

Galvin, K.M., M.J. Donovan, C.A. Lynch, R.I. Meyer, R.J. Paul, J.N. Lorenz, V. FairchildHuntress, K.L. Dixon, J.H. Dunmore, M.A. Gimbrone Jr, D. Falb, D. Huszar (2000) A role for smad6 in development and homeostasis of the cardiovascular system. Nat Genet 24: 171-174.

Gordon, K.J., M. Dong, E.M. Chislock, T.A. Fields, G.C. Blobe (2008) Loss of type III transforming growth factor beta receptor expression increases motility and invasiveness associated with epithelial to mesenchymal transition during pancreatic cancer progression. Carcinogenesis 29: 252-262.

Gordon, K.J., K.C. Kirkbride, T. How, G.C. Blobe (2009) Bone morphogenetic proteins induce pancreatic cancer cell invasiveness through a Smad1-dependent mechanism that involves matrix metalloproteinase-2. Carcinogenesis 30: 238-248.

Hata, A., G. Lagna, J. Massague, A. HemmatiBrivanlou (1998) Smad6 inhibits BMP/ Smad1 signaling by specifically competing with the Smad4 tumor suppressor. Genes Dev 12: 186-197.

Hayashida, T., M. Decaestecker, H.W. Schnaper (2003) Cross-talk between ERK MAP kinase and Smad signaling pathways enhances TGF-beta-dependent responses in human mesangial cells. FASEB J 17: 1576-1578.

He, T.C., S. Zhou, L.T. da Costa, J. Yu, K.W. Kinzler, B. Vogelstein (1998) A simplified system for generating recombinant adenoviruses. Proc Natl Acad Sci USA 95: 2509-2514.

Hempel, N., T. How, M. Dong, S.K. Murphy, T.A Fields, G.C. Blobe (2007) Loss of betaglycan expression in ovarian cancer: role in motility and invasion. Cancer Res 67: 5231-5238.

Keller, B.B., R.R. Markwald (1998) Embryology of the heart; in Alexander, R.W., R.C. Schlant, V. Fuster (eds): Hurst's the Heart, Arteries and Veins. New York, McGraw-Hill, pp 195-212.

Kirkbride, K.C., B.N. Ray, G.C. Blobe (2005) Cell-surface co-receptors: emerging roles in signaling and human disease. Trends Biochem Sci 30: 611-621.

Kirkbride, K.C., T.A. Townsend, M.W. Bruinsma, J.V. Barnett, G.C. Blobe (2008) Bone morphogenetic proteins signal through the transforming growth factor-beta type III receptor. J Biol Chem 283: 7628-7637.

Kretzschmar, M., J. Massague (1998) SMADs: mediators and regulators of TGF-beta signaling. Curr Opin Genet Dev 8: 103-111.

Lai, Y.T., K.B. Beason, G.P. Brames, J.S. Desgrosellier, M.C. Cleggett, M.V. Shaw, C.B. Brown, J.V. Barnett (2000) Activin receptorlike kinase 2 can mediate atrioventricular cushion transformation. Dev Biol 222: 1-11. 
Lee, N.Y., K.C. Kirkbride, R.D. Sheu, G.C. Blobe (2009) The transforming growth factor-beta type III receptor mediates distinct subcellular trafficking and downstream signaling of activin-like kinase (ALK)3 and ALK6 receptors. Mol Biol Cell 20: 4362-4370.

Levy, L., C.S. Hill (2005) Smad4 dependency defines two classes of transforming growth factor beta (TGF-beta) target genes and distinguishes TGF-beta-induced epithelial-mesenchymaltransition fromitsantiproliferative and migratory responses. Mol Cell Biol 25: 8108-8125.

Livak, K.J., T.D. Schmittgen (2001) Analysis of relative gene expression data using real-time quantitative PCR and the 2(-Delta Delta C(T)) Method. Methods 25: 402-408.

Lopez-Casillas, F., S. Cheifetz, J. Doody, J.L. Andres, W.S. Lane, J. Massague (1991) Structure and expression of the membrane proteoglycan betaglycan, a component of the TGF-beta receptor system. Cell 67: 785-795.

Lopez-Casillas, F., J.L. Wrana, J. Massague (1993) Betaglycan presents ligand to the TGF beta signaling receptor. Cell 73: 1435-1444.

Ma, L., M.F. Lu, R.J. Schwartz, J.F. Martin (2005) Bmp2 is essential for cardiac cushion epithelial-mesenchymal transition and myocardial patterning. Development 132: 5601-5611.

Masszi, A., C. Di Ciano, G. Sirokmany, W.T. Arthur, O.D. Rotstein, J. Wang, C.A. McCulloch, L. Rosivall, I. Mucsi, A. Kapus (2003) Central role for Rho in TGF-beta1induced alpha-smooth muscle actin expression during epithelial-mesenchymal transition. Am J Physiol Renal Physiol 284: F911F924.

Mercado-Pimentel, M.E., A.D. Hubbard, R.B. Runyan (2007) Endoglin and Alk5 regulate epithelial-mesenchymal transformation during cardiac valve formation. Dev Biol 304: 420-432.

-Miyazono, K., S. Maeda, T. Imamura (2005) $\mathrm{BMP}$ receptor signaling: transcriptional targets, regulation of signals, and signaling cross-talk. Cytokine Growth Factor Rev 16: 251-263.

Mythreye, K., G.C. Blobe (2009a) Proteoglycan signaling co-receptors: roles in cell adhesion, migration and invasion. Cell Signal 21: 1548-1558.

Mythreye, K., G.C. Blobe (2009b) The type III TGF-beta receptor regulates epithelial and cancer cell migration through beta-arrestin2-mediated activation of $\mathrm{Cdc} 42$. Proc Natl Acad Sci USA 106: 8221-8226.

-Nakajima, A., Y. Ito, M. Asano, M. Maeno, K. Iwata, N. Mitsui, N. Shimizu, X.M. Cui, C.F. Shuler (2007) Functional role of transforming growth factor-beta type III receptor during palatal fusion. Dev Dyn 236: 791-801.
Ozdamar, B., R. Bose, M. Barrios-Rodiles, H.R. Wang, Y. Zhang, J.L. Wrana (2005) Regulation of the polarity protein Par6 by TGFbeta receptors controls epithelial cell plasticity. Science 307: 1603-1609.

Potenta, S., E. Zeisberg, R. Kalluri (2008) The role of endothelial-to-mesenchymal transition in cancer progression. Br J Cancer 99: 1375-1379.

Reeves, R., D.D. Edberg, Y. Li (2001) Architectural transcription factor $\operatorname{HMGI}(\mathrm{Y})$ promotes tumor progression and mesenchymal transition of human epithelial cells. Mol Cell Biol 21: 575-594.

Rivera-Feliciano, J., C.J. Tabin (2006) Bmp2 instructs cardiac progenitors to form the heartvalve-inducing field. Dev Biol 295: 580-588.

Sadler, T. (1985) Cardiovascular system; in Sadler, T.W. (ed): Langman's Medical Embryology. Baltimore, Williams and Wilkins, pp 168-195.

-Sahai, E., R. Garcia-Medina, J. Pouyssegur, E. Vial (2007) Smurf1 regulates tumor cell plasticity and motility through degradation of RhoA leading to localized inhibition of contractility. J Cell Biol 176: 35-42.

Sanford, L.P., I. Ormsby, A.C. Gittenberger-de Groot, H. Sariola, R. Friedman, G.P. Boivin, E.L. Cardell, T. Doetschman (1997) TGFbeta2 knockout mice have multiple developmental defects that are non-overlapping with other TGFbeta knockout phenotypes. Development 124: 2659-2670.

Shi, Y., J. Massague (2003) Mechanisms of TGFbeta signaling from cell membrane to the nucleus. Cell 113: 685-700.

-Shull, M.M., I. Ormsby, A.B. Kier, S. Pawlowski, R.J. Diebold, M. Yin, R. Allen, C. Sidman, G. Proetzel, D. Calvin, N. Annunziata, T. Doetschman (1992) Targeted disruption of the mouse transforming growth factor-beta 1 gene results in multifocal inflammatory disease. Nature 359: 693-699.

Song, L., R. Fassler, Y. Mishina, K. Jiao, H.S. Baldwin (2007) Essential functions of Alk3 during AV cushion morphogenesis in mouse embryonic hearts. Dev Biol 301: 276-286.

Stenvers, K.L., M.L. Tursky, K.W. Harder, N. Kountouri, S. Amatayakul-Chantler, D. Grail, C. Small, R.A. Weinberg, A.M. Sizeland, H.J. Zhu (2003) Heart and liver defects and reduced transforming growth factor beta2 sensitivity in transforming growth factor beta type III receptor-deficient embryos. Mol Cell Biol 23: 4371-4385.

-Sugi, Y., H. Yamamura, H. Okagawa, R.R. Markwald (2004) Bone morphogenetic protein-2 can mediate myocardial regulation of atrioventricular cushion mesenchymal cell formation in mice. Dev Biol 269: 505-518.

-Thiery, J.P. (2002) Epithelial-mesenchymal transitions in tumour progression. Nat Rev Cancer 2: $442-454$.
Townsend, T.A., J.L. Wrana, G.E. Davis, J.V. Barnett (2008) Transforming growth factor-beta-stimulated endocardial cell transformation is dependent on Par6c regulation of RhoA. J Biol Chem 283: 13834-13841.

-Turley, R.S., E.C. Finger, N. Hempel, T. How, T.A. Fields, G.C. Blobe (2007) The type III transforming growth factor-beta receptor as a novel tumor suppressor gene in prostate cancer. Cancer Res 67: 1090-1098.

Wallez, Y., P. Huber (2007) Endothelial adherens and tight junctions in vascular homeostasis, inflammation and angiogenesis. Biochim Biophys Acta 1778: 794-809.

Wang, H.R., Y. Zhang, B. Ozdamar, A.A. Ogunjimi, E. Alexandrova, G.H. Thomsen, J.L. Wrana (2003) Regulation of cell polarity and protrusion formation by targeting RhoA for degradation. Science 302: 1775-1779.

Wang, J., S. Sridurongrit, M. Dudas, P. Thomas, A. Nagy, M.D. Schneider, J.A. Epstein, V. Kaartinen (2005) Atrioventricular cushion transformation is mediated by ALK2 in the developing mouse heart. Dev Biol 286: 299310.

Wang, X.F., H.Y. Lin, E. Ng-Eaton, J. Downward, H.F. Lodish, R.A. Weinberg (1991) Expression cloning and characterization of the TGF-beta type III receptor. Cell 67: 797-805.

Ward, S.M., A.P. Gadbut, D. Tang, A.G. Papageorge, L. Wu, G. Li, J.V. Barnett, J.B. Galper (2002) TGFbeta regulates the expression of G alpha(i2) via an effect on the localization of ras. J Mol Cell Cardiol 34: 1217-1226.

Wrana, J.L., L. Attisano, R. Wieser, F. Ventura, J. Massague (1994) Mechanism of activation of the TGF-beta receptor. Nature 370: 341-347.

Xie, L., B.K. Law, A.M. Chytil, K.A. Brown, M.E. Aakre, H.L. Moses (2004) Activation of the Erk pathway is required for TGF-betal-induced EMT in vitro. Neoplasia 6: 603-610.

You, H.J., M.W. Bruinsma, T. How, J.H. Ostrander, G.C. Blobe (2007) The type III TGF-beta receptor signals through both $S \operatorname{mad} 3$ and the p38 MAP kinase pathways to contribute to inhibition of cell proliferation. Carcinogenesis 28: 2491-2500.

You, H.J., T. How, G.C. Blobe (2009) The type III transforming growth factor-beta receptor negatively regulates nuclear factor kappa $B$ signaling through its interaction with betaarrestin2. Carcinogenesis 30: 1281-1287.

Zeisberg, E.M., O. Tarnavski, M. Zeisberg, A.L. Dorfman, J.R. McMullen, E. Gustafsson, A. Chandraker, X. Yuan, W.T. Pu, A.B. Roberts, E.G. Neilson, M.H. Sayegh, S. Izumo, R. Kalluri (2007) Endothelial-to-mesenchymal transition contributes to cardiac fibrosis. Nat Med 13: 952-961.

Zhao, G.Q. (2003) Consequences of knocking out BMP signaling in the mouse. Genesis 35 : 43-56. 